\title{
Swimming three ice miles within fifteen hours
}

\author{
Stjepanovic, Mirko ; Nikolaidis, Pantelis Theodoros ; Knechtle, Beat
}

\begin{abstract}
Ice Mile swimming (1608 $\mathrm{m}$ in water of below $5{ }^{\circ} \mathrm{Celsius}$ ) is becoming increasingly popular. This case study aimed to identify body core temperature and selected haematological and biochemical parameters before and after repeated Ice Miles. An experienced ice swimmer completed three consecutive Ice Miles within $15 \mathrm{~h}$. Swim times, body core temperatures, and selected urinary and haematological parameters were recorded. Body core temperature reached its maximum between 5,8 and $15 \mathrm{~min}$ after immersion $\left(37.7^{\circ} \mathrm{C}, 38.1^{\circ} \mathrm{C}\right.$, and $38.0^{\circ} \mathrm{C}$, respectively). The swimmer suffered hypothermia during the first Ice Mile $\left(35.4^{\circ} \mathrm{C}\right)$ and body core temperature dropped furthermore to $34.5^{\circ} \mathrm{C}$ during recovery after the first Ice Mile. He developed a metabolic acidosis in both the first and the last Ice Mile $\left(\mathrm{pH} 7.31\right.$ and $\mathrm{pH}$ 7.34, respectively). We observed hyperkalaemia $\left(\left[\mathrm{K}^{+}\right]>5.5\right.$ $\mathrm{mM}$ ) after the second Ice Mile (6.9 $\mathrm{mM})$. This was followed by a drop in $\left[\mathrm{K}^{+}\right]$to $3.7 \mathrm{mM}$ after the third Ice Mile. Anticipatory thermogenesis (i.e. an initial increase of body core temperature after immersion in ice cold water) seems to be a physiological response in a trained athlete. The results suggest that swimming in ice-cold water leads to a metabolic acidosis, which the swimmer compensates with hyperventilation (i.e. leading to respiratory alkalosis). The shift of serum $\left[\mathrm{K}^{+}\right]$could increase the risk of a cardiac arrhythmia. Further studies addressing the physiology and potential risks of Ice Mile swimming are required to substantiate this finding.
\end{abstract}

DOI: https://doi.org/10.4077/CJP.2017.BAF467

Posted at the Zurich Open Repository and Archive, University of Zurich ZORA URL: https://doi.org/10.5167/uzh-139282

Journal Article

Originally published at:

Stjepanovic, Mirko; Nikolaidis, Pantelis Theodoros; Knechtle, Beat (2017). Swimming three ice miles within fifteen hours. Chinese Journal of Physiology, 60(4):197-206.

DOI: https://doi.org/10.4077/CJP.2017.BAF467 


\title{
Swimming Three Ice Miles within Fifteen Hours
}

\author{
Mirko Stjepanovic, Pantelis T. Nikolaidis, and Beat Knechtle* \\ Institute of Primary Care, University of Zurich, Zurich, Switzerland \\ Exercise Physiology Laboratory, Nikaia, Greece \\ Gesundheitszentrum St. Gallen, St. Gallen, Switzerland
}

\begin{abstract}
Ice Mile swimming (1608 $\mathrm{m}$ in water of below $\left.5{ }^{\circ} \mathrm{Celsius}\right)$ is becoming increasingly popular. This case study aimed to identify body core temperature and selected haematological and biochemical parameters before and after repeated Ice Miles. An experienced ice swimmer completed three consecutive Ice Miles within $15 \mathrm{~h}$. Swim times, body core temperatures, and selected urinary and haematological parameters were recorded. Body core temperature reached its maximum between 5,8 and 15 min after immersion $\left(37.7^{\circ} \mathrm{C}, 38.1^{\circ} \mathrm{C}\right.$, and $38.0^{\circ} \mathrm{C}$, respectively). The swimmer suffered hypothermia during the first Ice Mile $\left(35.4^{\circ} \mathrm{C}\right)$ and body core temperature dropped furthermore to $34.5^{\circ} \mathrm{C}$ during recovery after the first Ice Mile. He developed a metabolic acidosis in both the first and the last Ice Mile (pH 7.31 and pH 7.34, respectively). We observed hyperkalaemia $\left(\left[\mathrm{K}^{+}\right]>5.5 \mathrm{mM}\right)$ after the second Ice Mile $(6.9 \mathrm{mM})$. This was followed by a drop in $\left[\mathrm{K}^{+}\right]$to3.7 $\mathrm{mM}$ after the third Ice Mile. Anticipatory thermogenesis (i.e. an initial increase of body core temperature after immersion in ice cold water) seems to be a physiological response in a trained athlete. The results suggest that swimming in ice-cold water leads to a metabolic acidosis, which the swimmer compensates with hyperventilation (i.e. leading to respiratory alkalosis). The shift of serum $\left[\mathrm{K}^{+}\right]$could increase the risk of a cardiac arrhythmia. Further studies addressing the physiology and potential risks of Ice Mile swimming are required to substantiate this finding.
\end{abstract}

Key Words: body fat, hypothermia, open-water swimming

\section{Introduction}

Swimming races are mainly held as indoor pool competitions $(18,30)$, but can also be held as openwater competitions. Open-water swimming, such as the 'English Channel Crossing', is of increasing popularity (8). Similar trends have been observed in freshwater and indoor ultra-endurance swimming, where the number of participants and finishers has increased in recent years $(7,9,19,20)$.

A rather young discipline in open-water swimming is the so-called Ice Mile swimming. It is defined as swimming a distance of $1608 \mathrm{~m}$ in water temperatures at or below $5^{\circ} \mathrm{C}$. The swim must be unassisted and the swimmer must wear one pair of goggles, a cap and a standard swimming costume. ${ }^{1}$
Important issues in cold-water swimming are afterdrop (i.e. the fall in body core temperature after a performance in the cold). The usual core temperature of healthy rested adult humans ranges between $36.5^{\circ} \mathrm{C}$ and $37.5^{\circ} \mathrm{C}$. Physiological hypothermia is defined as a body core temperature equal to or lower than $36.0^{\circ} \mathrm{C}$ (13).

Hypothermia during or after ice swimming (i.e. afterdrop) presents a great danger with potentially fatal consequences (10). A study published in 1946 showed that people immersed in water colder than $6^{\circ} \mathrm{C}$ after a shipwreck usually died of hypothermia within $75 \min$ (24). In 1969, Keatinge et al. conducted several studies investigating the dangers of swimming in cold water (15). These authors concluded that swimming in cold water had be abandoned partly

\footnotetext{
Corresponding author: Prof. Dr. med. Beat Knechtle, Gesundheitszentrum St. Gallen, Vadianstrasse 26, 9001 St. Gallen, Switzerland, Tel: +41(0) 7122693 00, Fax: +41 (0) 7122693 01, E-Mail: beat.knechtle@hispeed.ch

${ }^{1}$ International Ice Swimming Association (IISA), www.internationaliceswimming.com

Received: September 10, 2016; Revised (Final Version): December 16, 2016; Accepted: January 19, 2017.

(C2017 by The Chinese Physiological Society and Airiti Press Inc. ISSN : 0304-4920. http://www.cps.org.tw
} 
because of respiratory reflexes in thin men shortly after immersion (i.e. skinfold thickness less than $8 \mathrm{~mm}$ ) and due to hypothermia in overweight men (i.e. body mass index, BMI, higher than $25 \mathrm{~kg} / \mathrm{m}^{2}$ and skinfold thickness thicker than $9.5 \mathrm{~mm}$ ) (15). Afterdrop was investigated in 11 subjects following the 'New Year's Day Alcatraz Swim' competition in January 1998, where hypothermia was observed in only one subject and afterdrop in 10 of the 11 subjects (26).

However, it is possible that low body core temperature is beneficial. With increasing frequency, hypothermia is used to prevent or mitigate various types of neurologic injury (27). Side effects of hypothermia include immunosuppression with increased infection risk, cold diuresis and hypovolemia, electrolyte disorders, insulin resistance, impaired drug clearance, and mild coagulopathy (27). A risk of clinically significant arrhythmias occurs only if core temperature decreases below $30^{\circ} \mathrm{C}(26,27)$.

Only a few scientific studies investigating body core temperature during swimming in water colder than $5^{\circ} \mathrm{C}$ do exist $(6,15,21,25)$. For example, Noakes et al. reported body core temperature responses in a single individual to swims of $1 \mathrm{~km}$ or longer in ice cold water $\left(0-3^{\circ} \mathrm{C}\right)$, where they found that the swimmer was able to maintain a body core temperature above $36^{\circ} \mathrm{C}$ during a swim of $30 \mathrm{~min}$ in water at a temperature of $2-3^{\circ} \mathrm{C}(25)$. Similarly, in a case study with one swimmer successfully completing two Ice Miles body core temperature dropped $50 \mathrm{~min}$ after swimming one Ice Mile to $34.5^{\circ} \mathrm{C}(21)$.

As far as we know, no athlete ever tried to swim repeatedly in ice cold water and no study investigated how hematological and biochemical parameters, electrolytes and $\mathrm{pH}$-value react to such an extreme environment. In the present case study, we followed an experienced ice swimmer who intended to swim as many Ice Miles as possible in a row within $24 \mathrm{~h}$.

\section{Materials and Methods}

\section{Ethics Approval}

The experiment was approved by the Ethical Committee of the Kanton St. Gallen, Switzerland, and the swimmer gave his informed written consent for data collection and publication of the data.

\section{The Subject}

The subject was an experienced open-water ultra and ice swimmer (57 years old, $103 \mathrm{~kg}$ body mass,
$1.76 \mathrm{~m}$ body height, $33.2 \mathrm{~kg} / \mathrm{m}^{2}$ BMI). He was the first swimmer ever to cross the Fehmarn-Belt from Fehmarn (Germany) to Rødby (Denmark) and back to Fehmarn (i.e. double crossing, $2 \times 25 \mathrm{~km}, 16^{\circ} \mathrm{C}$ water temperature) in $2011 .^{2}$ In 2012 , he completed a 6-h swim in water colder than $10^{\circ} \mathrm{C}(28)$. In 2015 , he swam two Ice Miles in water colder than $5^{\circ} \mathrm{C}(21)$. The subject was without any previously diagnosed medical conditions, was not taking any medication and no history of non-freezing cold injury such as loss of sensation, skin damage/infection, or nerve damage $(21,28)$.

\section{The Event}

The experiment was designed as a case study with one participant. The athlete started the first Ice Mile on February 6, 2016, at 00:45 a.m. in the harbor of Paderborn at the Lake Lippe, Germany. The water had a temperature of $4.7-5.0^{\circ} \mathrm{C}$ one meter below surface. For each Ice Mile, the swimmer was followed by two rescue boats. Two experienced divers were ready for immediate rescue, if needed. A medical team was also on board. After each Ice Mile, the swimmer left the water to recover.

\section{Methods}

Given the results from several trainings prior to this event shown in Table 1, we hypothesized that it would be possible to swim five Ice Miles within $24 \mathrm{~h}$ and each Ice Mile should take about $40 \mathrm{~min}$ to complete. The longest interval from starting an Ice Mile to recovering to $37^{\circ} \mathrm{C}$ body core temperature was $4: 36 \mathrm{~h}: \mathrm{min}$. We planned that the athlete would complete as many Ice Miles as possible in daylight and therefore, the first start was set to 00:45 a.m. The intervals of the starts of the different Ice Miles were set between 4:30 h:min and 6:00 h:min. The swimming distance was measured using a GPS unit (Spot Gen3 Satellite messenger, www.findmespot. $\mathrm{eu} / \mathrm{gm})$. During all Ice Miles, the athlete wore his swimming trunks and swimming goggles.

Before (15 min) and after (20 min) each Ice Mile, we measured selected blood and urine parameters. We measured body core temperature continuously using the thermoelectric probes Endotherm ${ }^{\circledR}$ (EndoTherm $\mathrm{GmbH}$, Arlesheim, Switzerland). Endotherm ${ }^{\circledR}$ measures temperatures from $-40^{\circ} \mathrm{C}$ to $+85^{\circ} \mathrm{C}$ with a resolution of $0.0625^{\circ} \mathrm{C}$ and a precision of $0.1^{\circ} \mathrm{C}$. The Endotherm ${ }^{\circledR}$ probes were programmed to take one measurement every $30 \mathrm{~s}$. The probes were applied 2:45 h:min before the start of the first swim. The probe was inserted in the rectum using a protective container provided by

\footnotetext{
${ }^{2}$ www.welt.de/regionales/stuttgart/article13511181/Stuttgarter-schwimmt-durch-Fehmarnbelt.html
} 


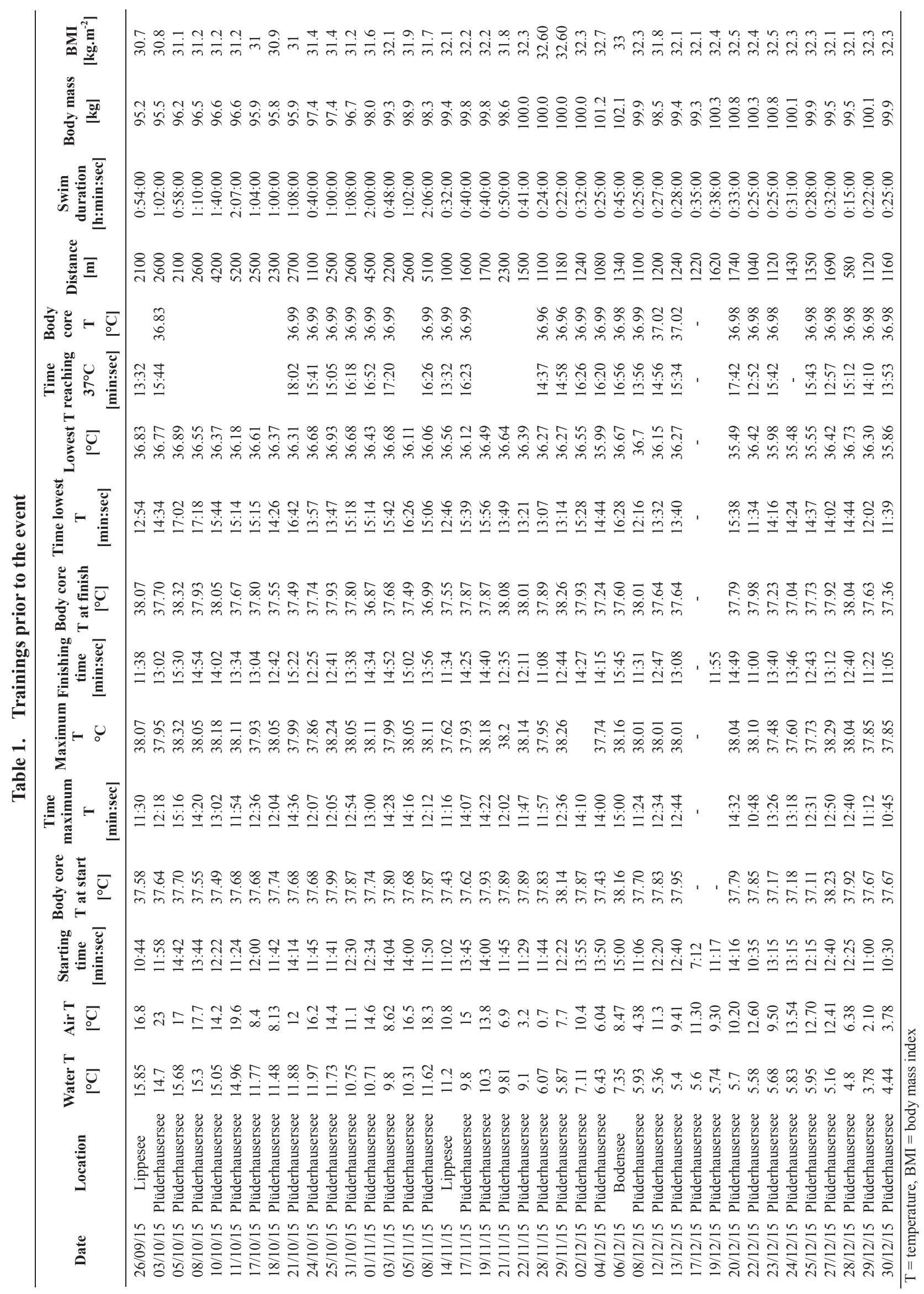


Table 2. Weather conditions

\begin{tabular}{lcccccc}
\hline \multicolumn{1}{c}{ Weather } & $\begin{array}{c}\text { Start } \\
\text { Mile 1 }\end{array}$ & $\begin{array}{c}\text { Finish } \\
\text { Mile 1 }\end{array}$ & $\begin{array}{c}\text { Start } \\
\text { Mile 2 }\end{array}$ & $\begin{array}{c}\text { Finish } \\
\text { Mile 2 }\end{array}$ & $\begin{array}{c}\text { Start } \\
\text { Mile 3 }\end{array}$ & $\begin{array}{c}\text { Finish } \\
\text { Mile 3 }\end{array}$ \\
\hline Air temperature, $C^{\circ}$ & 10.3 & 10 & 10.5 & 11.5 & 13.9 & 13.3 \\
Water temperature, $C^{\circ}$ & 4.7 & 4.7 & 4.8 & 4.8 & 4.9 & 4.9 \\
Barometric pressure, hpa & 1025.4 & 1024.5 & 1018.4 & 1018.2 & 1014.1 & 1014.2 \\
Wind, beaufortscale & 4 & 3 & 3 & 2 & 3 & 3 \\
Wind, direction & south & southwest & south & southeast & southwest & south \\
Light, lux & 0 & 0 & 34.2 & 33.3 & 23.9 & 18.6 \\
UV-Index & 0 & 0 & 1 & 2 & 1 & 1 \\
\hline
\end{tabular}

the manufacturer. Tympanic temperature was measured after $(5 \mathrm{~min})$ the first two Ice Miles, using a resistance thermometer Cosinuss ${ }^{\circledR}$ sensor $\left(\right.$ Cosinuss $^{\circ}$, München, Germany). After the third Ice Mile, it was not attached because of the distraction caused by a deep cut in the foot that he suffered from as he left the water. The blood samples were taken from the ear lobe and analysed using the i-STAT ${ }^{\circledR}$ (Axonlab, Baden, Switzerland) system using CHEM 8+ (i.e. [Na], $[\mathrm{K}],[\mathrm{Cl}], \mathrm{TCO}_{2}$, anion gap, calcium, glucose, creatinine and haemoglobin) and CG4+ cartridges (i.e. $\mathrm{pH}$ value, $\mathrm{CO}_{2}, \mathrm{HCO}_{3}, \mathrm{O}_{2}$, base excess). The urine samples (i.e. urine specific gravity, urine $\mathrm{pH}$ value, urine glucose, urine nitrite, and urine protein) were analysed using the Combur Test ${ }^{\circledR}$ (Roche, Basel, Switzerland). Moreover, we measured body composition employing the 'BC-568 Segmental Body Composition Analyser' (Tanita ${ }^{\mathrm{TM}}$, Tokyo, Japan) to determine body fat percentage, lean body mass, fat mass, bone mass and body weight. The analyser measures weight with increments of $0.1 \mathrm{~kg}$ and body fat increments with $0.1 \%$.

Before the first Ice Mile he only drank a small sip of water and ate some sweets. Before the second Ice Mile he drank water, ate a slice of bread with cheese, sweets $(100 \mathrm{~g}=67 \mathrm{~g}$ carbohydrate, $10 \mathrm{~g}$ fat, $2.4 \mathrm{~g}$ protein) and a cookie. Before the third Ice Mile he drank a non-alcoholic beer and ate half a jar of plum butter (ca $250 \mathrm{~g}=125 \mathrm{~g}$ carbohydrates), a soup and two pieces of cake.

The weather data (i.e. air temperature, barometric pressure $\mathrm{hPa}$, wind beaufort-scale and wind direction, light intensity [lux] and UV-Index) was provided by the Deutsche Lebens-Rettungs-Gesellschaft, the largest voluntary lifesaving organization in the world. ${ }^{3}$ The data were continuously measured by the weather station at the rescue station (Table 2). Water temperature was measured one meter below

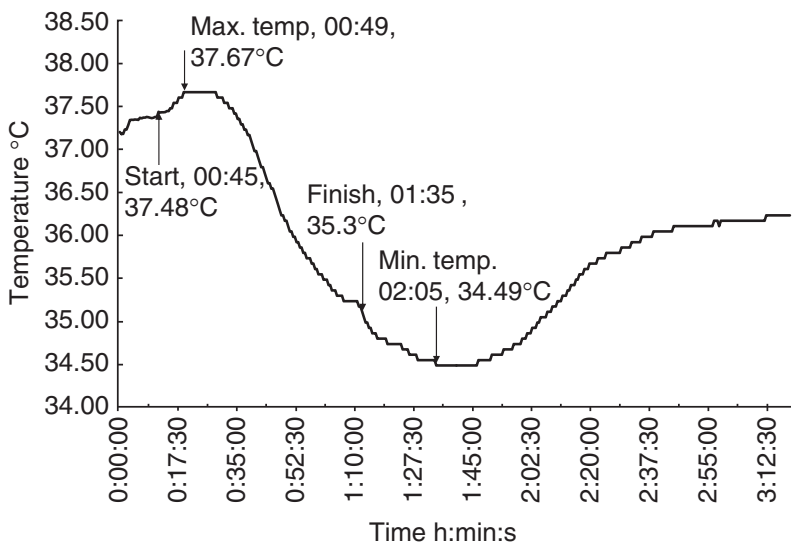

Fig. 1. Change in body core temperature during the first Ice Mile.

surface with three different thermometers using thermoelectric probes from Endotherm ${ }^{\mathbb{B}}$ (EndoTherm $\mathrm{GmbH}$, Arlesheim, Switzerland) and LCD handoperated thermometers DT-300 (Voltcraft, Hirschau, Germany) with a temperature accuracy of $0.1^{\circ} \mathrm{C}$.

\section{Results}

\section{The First Ice Mile}

The subject started his first Ice Mile on February 13,2016 , at 00:45 a.m. at a water temperature of $4.7^{\circ} \mathrm{C}$. During the swim, he lost orientation due to the darkness, which led to a prolonged swim time of $50 \mathrm{~min}$. He changed between freestyle and breaststroke. At the start, his body core temperature was at $37.5^{\circ} \mathrm{C}$ and reached the maximum of $37.7^{\circ} \mathrm{C}$ after $5 \mathrm{~min}$ of swimming (Fig. 1). At the end of the Ice Mile, body core temperature had reached $35.3^{\circ} \mathrm{C}$. Thus, he developed hypothermia during the swim. The lowest point was reached $30 \mathrm{~min}$ after leaving the water at

\footnotetext{
${ }^{3}$ Deutsche Lebensrettungsgesellschaft, www.dlrg.de
} 
Table 3. Blood parameters, bio impedance and urinary parameters before and after the first Ice Mile

\begin{tabular}{|c|c|c|c|c|c|}
\hline Parameters & Pre & Post & Change absolute & Percent change & Reference Range Arterial \\
\hline Sodium, mM & 139 & 139 & 0 & $0.00 \%$ & $138-146 \mathrm{mM}$ \\
\hline Potassium, mM & 5 & 5.1 & 0.1 & $1.96 \%$ & $3.5-5.5 \mathrm{mM}$ \\
\hline Chloride, $\mathrm{mM}$ & 108 & 111 & 3 & $2.70 \%$ & $98-109 \mathrm{mM}$ \\
\hline $\mathrm{TCO}_{2}, \mathrm{mM}$ & 21 & 15 & -6 & $-40.00 \%$ & $24-29 \mathrm{mM}$ \\
\hline Anion Gap*, mM & 16 & 19 & 3 & $15.79 \%$ & $10-20 \mathrm{mM}$ \\
\hline Ionized Calcium, mM & 1.19 & 1.17 & -0.02 & $-1.71 \%$ & $1.12-1.32 \mathrm{mM}$ \\
\hline Glucose, mM & 7 & 12.8 & 5.8 & $45.31 \%$ & $3.9-5.8 \mathrm{mM}$ \\
\hline Urea, mg/dl & 6.5 & 5.9 & -0.6 & $-10.17 \%$ & $8-26 \mathrm{mg} / \mathrm{dl}$ \\
\hline Creatinine, $\mathrm{mg} / \mathrm{dl}$ & 48 & 59 & 11 & $18.64 \%$ & $0.6-1.3 \mathrm{mg} / \mathrm{dl}$ \\
\hline Lactate, $\mathrm{mM}$ & 1.21 & 6.01 & 4.8 & $79.87 \%$ & $0.36-1.25 \mathrm{mM}$ \\
\hline Hematocrit, \% & 48 & 48 & 0 & $0.00 \%$ & $38-51 \% \mathrm{PCV}$ \\
\hline Hemoglobin*, g/l & 163 & 163 & 0 & $0.00 \%$ & $120-170 \mathrm{~g} / \mathrm{l}$ \\
\hline $\mathrm{pH}$ & 7.401 & 7.313 & -0.088 & $-1.20 \%$ & $7.35-7.45$ \\
\hline $\mathrm{pCO}_{2}, \mathrm{kPa}$ & 5.14 & 4.99 & -4.11 & $-82.36 \%$ & $4.67-6.00 \mathrm{kPa}$ \\
\hline $\mathrm{PO}_{2}, \mathrm{kPa}$ & 9.1 & 6.3 & -2.8 & $-44.44 \%$ & $10.7-13 \mathrm{kPa}$ \\
\hline Total $\mathrm{CO}_{2}{ }^{*}, \mathrm{mM}$ & 25 & 20 & -5 & $-25.00 \%$ & $23-27 \mathrm{mM}$ \\
\hline $\mathrm{HCO}_{3}{ }^{*}, \mathrm{mM}$ & 23.9 & 19 & -4.9 & $-25.79 \%$ & $23-27 \mathrm{mM}$ \\
\hline Base Excess*, mM & -1 & -7 & -6 & $85.71 \%$ & $(-2)-(+3) \mathrm{mM}$ \\
\hline $\mathrm{O}_{2} *$ saturation, $\%$ & 93 & 80 & -13 & $-16.25 \%$ & $95-98 \%$ \\
\hline Urine specific gravity, $(\mathrm{g} / \mathrm{ml})$ & 1.015 & 1.025 & 0.01 & $0.99 \%$ & \\
\hline Urine $\mathrm{pH}$ & 8 & 5 & -3 & $-37.50 \%$ & \\
\hline Urine glucose & Neg. & Neg. & 0 & 0 & \\
\hline Total body water (L) & 55.5 & & & & \\
\hline Lean body mass $(\mathrm{kg})$ & 72.2 & & & & \\
\hline Fat mass $(\mathrm{kg})$ & 26.4 & & & & \\
\hline Bone mass $(\mathrm{kg})$ & 3.7 & & & & \\
\hline Body mass $(\mathrm{kg})$ & 103 & & & & \\
\hline
\end{tabular}

Note: * calculated, $\mathrm{HCO}_{3-}$ - Hydrogen carbonate

$34.5^{\circ} \mathrm{C}$. The $\mathrm{pO}_{2}$ and the $\mathrm{pCO}_{2}$ decreased (Table 3). There was a large increase of plasma lactate and plasma glucose levels and a drop of $\mathrm{pH}$. The urine specific gravity increased and the urine $\mathrm{pH}$ decreased.

\section{The Second Ice Mile}

The swimmer started his second Ice Mile on February 13,2016, at 10:40 a.m. at a water temperature of $4.8^{\circ} \mathrm{C}$. It was sunny, windy and the swimmer had no problems with orientation. His body core temperature was $37.9^{\circ} \mathrm{C}$ at the start and rose up to $38.1^{\circ} \mathrm{C}$ after 8 min of swimming (Fig. 2). He completed the second Ice Mile within 42 min and body core temperature was at $36.6^{\circ} \mathrm{C}$ when he left the water. Thereafter, body core temperature decreased

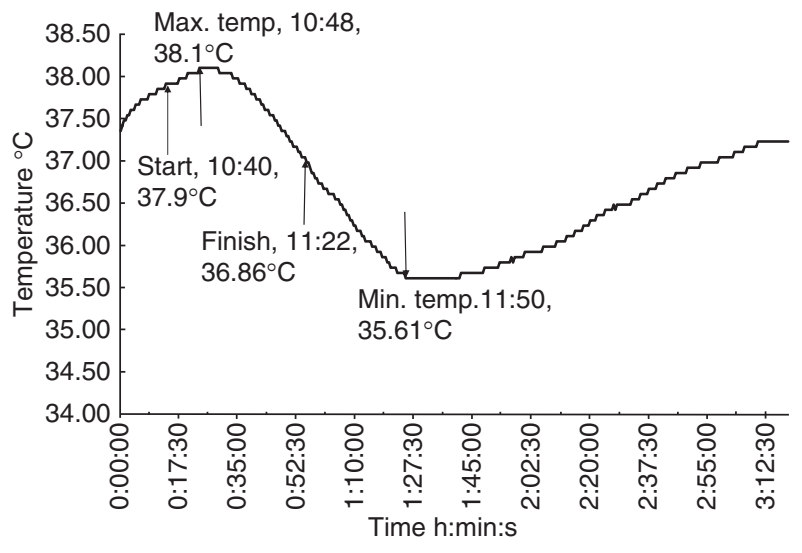

Fig. 2. Change in body core temperature during the second Ice Mile. 
Table 4. Blood parameters, bioimpendance and urinary parameters before and after the second Ice Mile

\begin{tabular}{|c|c|c|c|c|c|}
\hline Parameters & Pre & Post & Change absolute & Percent change & Reference Range Arterial \\
\hline Sodium, mM & 139 & 135 & -4 & $2.88 \%$ & $138-146 \mathrm{mM}$ \\
\hline Potassium, mM & 5.6 & 6.9 & 1.3 & $-23.21 \%$ & $3.5-5.5 \mathrm{mM}$ \\
\hline Chloride, $\mathrm{mM}$ & 106 & 109 & 3 & $-2.83 \%$ & $98-109 \mathrm{mM}$ \\
\hline $\mathrm{TCO}_{2}, \mathrm{mM}$ & 21 & 19 & -2 & $9.52 \%$ & $24-29 \mathrm{mM}$ \\
\hline Anion Gap*, mM & 18 & 14 & -4 & $22.22 \%$ & $10-20 \mathrm{mM}$ \\
\hline Ionized Calcium, mM & 1.18 & 1.12 & -0.06 & $5.08 \%$ & $1.12-1.32 \mathrm{mM}$ \\
\hline Glucose, mM & 12.5 & 9.3 & -3.2 & $25.60 \%$ & $3.9-5.8 \mathrm{mM}$ \\
\hline Urea, mg/dl & 7.5 & 7.6 & 0.1 & $-1.33 \%$ & $8-26 \mathrm{mg} / \mathrm{dl}$ \\
\hline Creatinine, $\mathrm{mg} / \mathrm{dl}$ & 56 & 57 & 1 & $-1.79 \%$ & $0.6-1.3 \mathrm{mg} / \mathrm{dl}$ \\
\hline Lactate, mM & 1.78 & 2.99 & 1.21 & $-67.98 \%$ & $0.36-1.25 \mathrm{mM}$ \\
\hline Hematocrit, \% & 50 & 49 & -1 & $2.00 \%$ & $38-51 \% \mathrm{PCV}$ \\
\hline Hemoglobin*, g/l & 170 & 167 & -3 & $1.76 \%$ & $120-170 \mathrm{~g} / 1$ \\
\hline $\mathrm{pH}$ & 7.424 & 7.407 & -0.017 & $0.23 \%$ & $7.35-7.45$ \\
\hline $\mathrm{pCO}_{2}, \mathrm{kPa}$ & 4.79 & 5 & 0.21 & $-4.38 \%$ & $4.67-6.00 \mathrm{kPa}$ \\
\hline $\mathrm{PO}_{2}, \mathrm{kPa}$ & 9.4 & 7.3 & -2.1 & $22.34 \%$ & $10.7-13 \mathrm{kPa}$ \\
\hline Total $\mathrm{CO}_{2}{ }^{*}, \mathrm{mM}$ & 25 & 25 & 0 & $0.00 \%$ & $23-27 \mathrm{mM}$ \\
\hline $\mathrm{HCO}_{3} *, \mathrm{mM}$ & 23.5 & 23.6 & 0.1 & $-0.43 \%$ & $23-27 \mathrm{mM}$ \\
\hline Base excess*, mM & -1 & -1 & 0 & $0.00 \%$ & $(-2)-(+3) \mathrm{mM}$ \\
\hline $\mathrm{O}_{2} *$ saturation, $\%$ & 94 & 88 & -6 & $6.38 \%$ & $95-98 \%$ \\
\hline Urine specific gravity, $(\mathrm{g} / \mathrm{ml})$ & 1.015 & 1.03 & 0.015 & $-1.48 \%$ & \\
\hline Urine $\mathrm{pH}$ & 6 & 5 & -1 & $16.67 \%$ & \\
\hline Urine glucose & Neg. & Neg. & & & \\
\hline Total body water (L) & 54.6 & & & & \\
\hline Lean body mass (kg) & 71 & & & & \\
\hline Fat mass $(\mathrm{kg})$ & 26.7 & & & & \\
\hline Bone mass (kg) & 3.7 & & & & \\
\hline Body mass (kg) & 101.9 & & & & \\
\hline
\end{tabular}

Note: * calculated, $\mathrm{HCO}_{3-}$ Hydrogen carbonate

reaching the nadir at $35.6^{\circ} \mathrm{C}$ after $38 \mathrm{~min}$. He had a faster recovery (i.e. body core temperature rose within two hours to $37^{\circ} \mathrm{C}$ ) with less shivering compared to the first Ice Mile. Lactate increased and blood $\mathrm{pH}$ remained within the normal range (Table 4). The $\mathrm{pCO}_{2}$ before the start was lower than after the first Ice Mile. The potassium level increased into a hyperkalemia (reference range: $3.5-5.5 \mathrm{mM}$ ). The sodium level dropped from $139 \mathrm{mM}$ to $135 \mathrm{mM}$. The urine specific gravity increased and the urine $\mathrm{pH}$ decreased.

\section{The Third Ice Mile}

The subject started the third Ice Mile on February 13,2016 , at 15:00 p.m. at a water temperature of

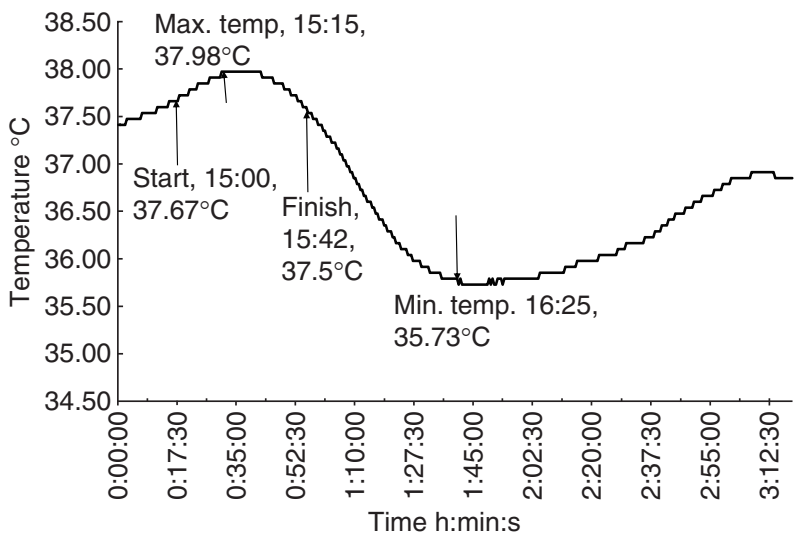

Fig. 3. Change in body core temperature during the first Ice Mile. 
Table 5. Blood parameters, bioimpendance and urinary parameters before and after the third Ice Mile

\begin{tabular}{|c|c|c|c|c|c|}
\hline Parameters & Pre & Post & Change absolute & Percent change & Reference Range Arterial \\
\hline Sodium, mM & 139 & 140 & 1 & $-0.72 \%$ & $138-146 \mathrm{mM}$ \\
\hline Potassium, mM & 5.7 & 3.7 & -2 & $35.09 \%$ & $3.5-5.5 \mathrm{mM}$ \\
\hline Chloride, $\mathrm{mM}$ & 108 & 105 & -3 & $2.78 \%$ & 98-109 mM \\
\hline $\mathrm{TCO}_{2}, \mathrm{mM}$ & 22 & 20 & -2 & $9.09 \%$ & $24-29 \mathrm{mM}$ \\
\hline Anion Gap*, mM & 16 & 19 & 3 & $-18.75 \%$ & $10-20 \mathrm{mM}$ \\
\hline Ionized Calcium, mM & 1.17 & 1.16 & -0.01 & $0.85 \%$ & $1.12-1.32 \mathrm{mM}$ \\
\hline Glucose, mM & 3.4 & 12.8 & 9.4 & $-276.47 \%$ & $3.9-5.8 \mathrm{mM}$ \\
\hline Urea, $\mathrm{mg} / \mathrm{dl}$ & 8.9 & 8.9 & 0 & $0.00 \%$ & $8-26 \mathrm{mg} / \mathrm{dl}$ \\
\hline Creatinine, mg/dl & 48 & 51 & 3 & $-6.25 \%$ & $0.6-1.3 \mathrm{mg} / \mathrm{dl}$ \\
\hline Lactate, $\mathrm{mM}$ & 1.31 & 3.15 & 1.84 & $-140.46 \%$ & $0.36-1.25 \mathrm{mM}$ \\
\hline Hematocrit, \% & 43 & 42 & -1 & $2.33 \%$ & $38-51 \% \mathrm{PCV}$ \\
\hline Hemoglobin*, g/l & 146 & 143 & -3 & $2.05 \%$ & $120-170 \mathrm{~g} / 1$ \\
\hline $\mathrm{pH}$ & 7.486 & 7.34 & -0.146 & $1.95 \%$ & $7.35-7.45$ \\
\hline $\mathrm{pCO}_{2}, \mathrm{kPa}$ & 4.71 & 5.66 & 0.95 & $-20.17 \%$ & $4.67-6.00 \mathrm{kPa}$ \\
\hline $\mathrm{PO}_{2}, \mathrm{kPa}$ & 8.8 & 8.3 & -0.5 & $5.68 \%$ & $10.7-13 \mathrm{kPa}$ \\
\hline Total $\mathrm{CO}_{2}{ }^{*}, \mathrm{mM}$ & 28 & 24 & -4 & $14.29 \%$ & $23-27 \mathrm{mM}$ \\
\hline $\mathrm{HCO}_{3}{ }^{*}, \mathrm{mM}$ & 26.7 & 22.9 & -3.8 & $14.23 \%$ & $23-27 \mathrm{mM}$ \\
\hline Base Excess*, mM & 3 & -3 & -6 & $200.00 \%$ & $(-2)-(+3) \mathrm{mM}$ \\
\hline $\mathrm{O}_{2} *$ saturation, $\%$ & 94 & 90 & -4 & $4.26 \%$ & $95-98 \%$ \\
\hline Urine specific gravity, $(\mathrm{g} / \mathrm{ml})$ & 1.025 & 1.03 & 0.005 & $0.49 \%$ & \\
\hline Urine $\mathrm{pH}$ & 6 & 5 & -1 & $-16.67 \%$ & \\
\hline Urine glucose & Neg. & 3.5 & & & \\
\hline Total body water (L) & 51.9 & & & & \\
\hline Lean body mass $(\mathrm{kg})$ & 68.4 & & & & \\
\hline Fat mass $(\mathrm{kg})$ & 29.7 & & & & \\
\hline Bone mass $(\mathrm{kg})$ & 3.5 & & & & \\
\hline Body mass $(\mathrm{kg})$ & 102.4 & & & & \\
\hline
\end{tabular}

Note: * calculated, $\mathrm{HCO}_{3 \text { - }}$ Hydrogen carbonate

$4.9^{\circ} \mathrm{C}$. Leaving the water for the third time, he suffered a deep cut at the right foot. The injury required three stitches and the swimmer decided to stop the project. The recovery was fast with almost no shivering. His body core temperature was at $37.6^{\circ} \mathrm{C}$ at the start and reached a maximum of $37.9^{\circ} \mathrm{C}$ after 6 min of swimming (Fig. 3). He completed the third Ice Mile after $41 \mathrm{~min}$ and his body core temperature was $37.5^{\circ} \mathrm{C}$ at the finish. Body core temperature dropped thereafter, reaching the nadir at $35.7^{\circ} \mathrm{C}$ after $36 \mathrm{~min}$. The hyperkalemia normalized to the lower end of the reference range (Table 5). Glucose and lactate concentration in blood increased and $\mathrm{pH}$ decreased. The $\mathrm{pCO}_{2}$ was even lower than after the second Ice Mile. Urine specific gravity increased and urine $\mathrm{pH}$ decreased.

\section{Discussion}

This case study demonstrates that an experienced amateur ice swimmer is able to complete three Ice Miles within $15 \mathrm{~h}$ without developing hypothermia. The results of different laboratory parameters indicated that ice swimming could lead to a metabolic acidosis, which the swimmer tries to compensate with hyperventilation (i.e. leading to respiratory alkalosis).

Body Core Temperature and Hypothermia 


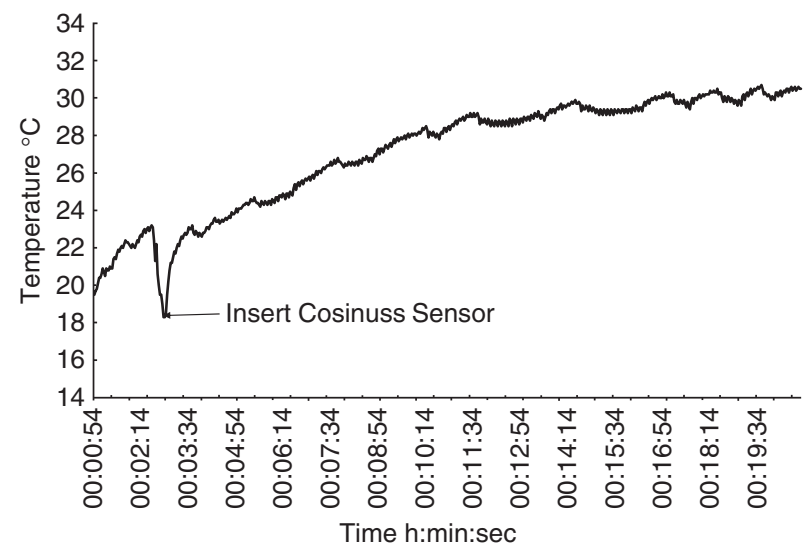

Fig. 4. Change in tympanic temperature after the first Ice Mile.

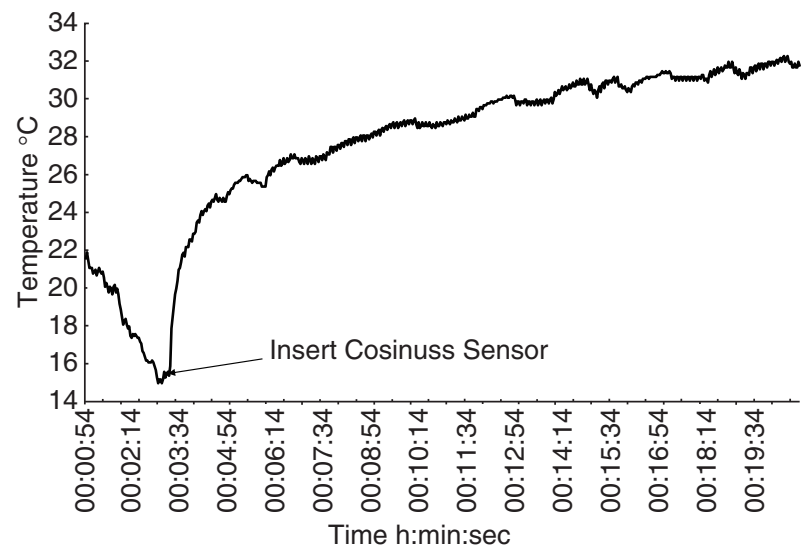

Fig. 5. Change in tympanic temperature after the second Ice Mile.

The first important finding was that the swimmer only developed hypothermia while swimming the first Ice Mile $\left(35.4^{\circ} \mathrm{C}\right)$. Nevertheless, he displayed an afterdrop in his body core temperature of $0.8^{\circ} \mathrm{C}$ after the first, $1.25^{\circ} \mathrm{C}$ after the second and $1.75^{\circ} \mathrm{C}$ after the third Ice Mile. This resulted in a mild accidental hypothermia $\left(34.5^{\circ} \mathrm{C}\right)$ after the first Ice Mile and physiological hypothermia $\left(<36^{\circ} \mathrm{C}\right)$ after the second $\left(35.6^{\circ} \mathrm{C}\right)$ and third Ice Mile $\left(35.7^{\circ} \mathrm{C}\right)$. This can be explained by the longer duration of the first Ice Mile that the subject completed in $50 \mathrm{~min}$ (4). He suffered the largest afterdrop $\left(1.75^{\circ} \mathrm{C}\right)$ after the third Ice Mile, where he had maintained the highest body core temperature during the swim.

Additionally, the data show that body core temperature increased within the first min of swimming which parallels the results of a similar study by Rüst et al. (28). Noakes et al. (25) described this phenomenon as 'anticipatory thermogenesis'. This seems to be a physiological response in trained athletes. Our swimmer's body core temperature reached its maximum between 5,8 and $15 \mathrm{~min}$ after immersion $\left(37.7^{\circ} \mathrm{C}\right.$, $38.1^{\circ} \mathrm{C}$, and $38.0^{\circ} \mathrm{C}$, respectively), with a relative change of $0.2^{\circ} \mathrm{C}-0.3^{\circ} \mathrm{C}$.

The prolonged recovery time after the first Ice Mile indicated the limiting duration for cold-water swims. For longer than $50 \mathrm{~min}$, the subject was in water at $4.7^{\circ} \mathrm{C}$ and he could maintain his body core temperature that was higher than the starting temperature for $20 \mathrm{~min}$ before it started to decrease. Another interesting finding was that his body core temperature increased by $0.31^{\circ} \mathrm{C}$ during the swim and he finished the third Ice Mile with an absolute body core temperature drop of only $0.17^{\circ} \mathrm{C}$ after $41 \mathrm{~min}$ in water of $4.9^{\circ} \mathrm{C}\left(37.7^{\circ} \mathrm{C}\right.$ at the start, $38.0^{\circ} \mathrm{C}$ maximum temperature, $37.5^{\circ} \mathrm{C}$ at the finish). His high $\mathrm{BMI}$, his wide experience in cold-water swimming and his anticipatory thermogenesis could explain how he maintained this temperature during $41 \mathrm{~min}$ in water of $4.9^{\circ} \mathrm{C}(17,21,25)$.

Another finding is that tympanic temperature does not seem suitable for measuring body core temperature during Ice Mile swimming. It substantially overestimates the severity and incidence of hypothermia (Figs. 4 and 5) (27). Tympanic temperature reflects peripheral skin temperature in our setting. The data show how the peripheral temperature gradually recovers over time.

\section{Blood Parameters}

The second important finding was that after the second Ice Mile, there was an increase of $\left[\mathrm{K}^{+}\right]$from $5.6 \mathrm{mM}$ to $6.9 \mathrm{mM}$. This could be explained by a $\mathrm{K}^{+}-$ shift from the muscle cells as shown in a study following intense rowing exercise where plasma $\left[\mathrm{K}^{+}\right]$ increased within the first $90 \mathrm{sec}$ and remained high during the exercise $(2,11,12)$. Another study regarding the consequences and dynamics in potassium shifts concluded that a rapid and pronounced increase of $\left[\mathrm{K}^{+}\right]$and a substantial loss of $\left[\mathrm{K}^{+}\right]$from the active skeletal muscle were very likely primary causes of fatigue with a fast recovery (29).

His sodium level dropped from $139 \mathrm{mM}$ to 135 $\mathrm{mM}$ after the second Ice Mile. The most probable explanation is overdrinking and accidental water swallowing during the Ice Mile (32) in combination with a cold-induced diuresis. In combination with a hyperkaliemia an adrenal insufficiency could also be considered.

Another important finding occurred after the third Ice Mile. Plasma $\left[\mathrm{K}^{+}\right]$decreased from $5.7 \mathrm{mM}$ to 3.7 $\mathrm{mM}$. This can be explained by the post-exercise reuptake of potassium into the muscle (i.e. $\mathrm{Na}^{+}-\mathrm{K}^{+}$pump) and hormonal control (i.e. epinephrine, $\beta$-agonists, and insulin) (29). Such low $\left[\mathrm{K}^{+}\right]$levels may pose a cardiovascular risk for individuals susceptible to arrhythmias. The effects of a decreased natriuresis 
after cold immersion and hypothermia, and changes in $\mathrm{H}^{+}$should also be considered as cause of secondary changes in $\mathrm{pH}$ and $\left[\mathrm{K}^{+}\right]$(33). However, this finding requires further investigation $(2,16)$. A systematic review of swimming-related deaths suggested that cardiac arrhythmias were the most likely etiology of a swimming-related death (1).

\section{Metabolic Acidosis}

The measured variables indicated that the swimmer developed a metabolic acidosis, which he compensated with a respiratory response. Most probably, the $50 \mathrm{~min}$ in ice cold water in the first Ice Mile were an enormous stress for his body. Plasma glucose increased to $12.8 \mathrm{mM}(+82.9 \%)$ (reference range: $3.9-5.8 \mathrm{mM}$ ) without any food intake before the start. Lactate concentration increased from $1.21 \mathrm{mM}$ up to $6.01 \mathrm{mM}$ (reference: $<2.3 \mathrm{mM}$ ) (31) causing a metabolic acidosis. His body compensated the situation respiratory by decreasing the $\mathrm{CO}_{2}$ pressure from 9.10 to $4.99 \mathrm{kPa}(-45.2 \%)$. Our swimmer had no shortness of breath or respiratory distress at any time of the Ice Mile. His rate of breathing was at $30-40 /$ min after each Ice Mile.

\section{Cold Induced Urticaria}

There are several cases of cold induced urticaria and anaphylactic reactions described after entering cold waters $(3,13,22)$. An IgE-mediated treatment has been shown to be safe and effective in patients with cold urticaria $(3,22)$.

\section{Strength, Weakness, Limitations and Implications for Future Research}

The strengths of this case study are the continuous measurements of body core temperature, swimming time and distance. Numerous biochemical and physiological parameters before and after each Ice Mile give further insight in physiological changes. A weakness is the "bedside"-testing with only one cartridge at the time. This required pricking the earlobe several times with short delays. For better precision, arterial blood could be taken instead of capillary blood (6 $\mathrm{mmHg}$ standard error) (33). A direct measure of $\mathrm{SpO}_{2}$ could be also considered. We also kept no exact track of the entire fluid intake. Another limitation of this study is the single-case design. Future research including a greater number of participants might yield more insights. The increase in plasma glucose and lactate is most probably due to the physical and thermal stress, this stress might be quantified with the measurements of salivary cortisol.

\section{Practical Applications}

The results of the current study suggest that is possible for an experienced swimmer with a high BMI to swim consecutive Ice Miles without suffering hypothermia during or after an Ice Mile, when he recovers to $37^{\circ} \mathrm{C}$ body core temperature between the attempts. In summary, the danger of hypothermia and hypo-/hyperkalaemia could increase the risk of an arrhythmia and based on our data, we do not recommend swimming several Ice Miles. The subject should be in a perfect state of health and have no previous heart condition that could affect his health. Further, a high BMI, a high fat mass and good weather conditions are recommended.

\section{Acknowledgments}

The authors would like to thank the athlete for participation in this study, the DLRG for providing shelter and support and Axonlab for providing the i-STAT.

\section{References}

1. Asplund, C.A. and Creswell, L.L. Hypothesised mechanisms of swimming-related death: a systematic review. Brit. J. Sports Med. 50: 1360-1366, 2016.

2. Atanasovska, T., Petersen, A.C., Rouffet, D.M., Billaut, F., Ng, I. and McKenna, M.J. Plasma $\mathrm{K}^{+}$dynamics and implications during and following intense rowing exercise. J. Appl. Physiol. 117: 6068, 2014.

3. Boyce, J.A. Successful treatment of cold-induced urticaria/ anaphylaxis with anti-IgE. J. Allergy Clin. Immunol. 117: 14151418, 2006.

4. Brannigan, D., Rogers, I.R., Jacobs, I., Montgomery, A., Williams, A. and Khangure, N. Hypothermia is a significant medical risk of mass participation long-distance open water swimming. Wilderness Environ. Med. 20: 14-18, 2009.

5. Debaty, G., Moustapha, I., Bouzat, P., Maignan, M., Blancher, M., Rallo, A., Brun, J., Chavanon, O., Danel, V., Carpentier, F., Payen, J.F. and Briot, R. Outcome after severe accidental hypothermia in the French Alps: A 10-year review. Resuscitation 93: 118-123, 2015.

6. Dugue, B. and Leppanen, E. Adaptation related to cytokines in man: effects of regular swimming in ice-cold water. Clin. Physiol. 20: 114-121, 2000.

7. Eichenberger, E., Knechtle, B., Knechtle, P., Rüst, C.A., Rosemann, T., Lepers, R. and Senn, O. Sex difference in open-water ultra-swim performance in the longest freshwater lake swim in Europe. J. Strength Cond. Res. 27: 1362-1369, 2013.

8. Eichenberger, E., Knechtle, B., Knechtle, P., Rüst, C.A., Rosemann, T. and Lepers, R. Best performances by men and women open-water swimmers during the 'English Channel Swim' from 1900 to 2010. J. Sports Sci. 30: 1295-1301, 2012.

9. Eichenberger, E., Knechtle, B., Rüst, C.A., Knechtle, P., Lepers, R. and Rosemann, T. No gender difference in peak performance in ultra-endurance swimming performance - analysis of the 'Zurich 12-h Swim' from 1996 to 2010. Chinese J. Physiol. 55: 346-351, 2012.

10. Graham, J.M. and Keatinge, W.R. Deaths in cold water. Brit. Med. J. 2: 18-19, 1978. 
11. Hallén, J. $\mathrm{K}^{+}$balance in humans during exercise. Acta Physiol. Scand. 156: 279-286, 1996.

12. Hart, S.R., Bordes, B., Hart, J., Corsino, D. and Harmon, D. Unintended perioperative hypothermia. Ochsner J. 11: 259-270, 2011.

13. Kaplan, A.P., Gray, L., Shaff, R.E., Horakova, Z. and Beaven, M.A. In vivo studies of mediator release in cold urticaria and cholinergic urticaria. J. Allergy Clin. Immunol. 55: 394-402, 1975.

14. Keatinge, W., Khartchenko, M., Lando, N. and Lioutov, V. Hypothermia during sports swimming in water below $11^{\circ} \mathrm{C}$. Brit. $J$. Sports Med. 35: 352-353, 2001.

15. Keatinge, W.R., Prys-Roberts, C. Cooper, K.E., Honour, A.J. and Haight, J. Sudden failure of swimming in cold water. Brit. Med. J. 1: 480-483, 1969.

16. Kjeldsen, K. Hypokalemia and sudden cardiac death. Exp. Clin. Cardiol. 15: 96-99, 2010.

17. Knechtle, B., Christinger, N., Kohler, G., Knechtle, P. and Rosemann, T. Swimming in ice cold water. Ir. J. Med. Sci. 178: 507$511,2009$.

18. Knechtle, B., Nikolaidis, P.T., Rosemann, T. and Rüst, C.A. Performance trends in age group breaststroke swimmers in the FINA World Championships 1986-2014. Chinese J. Physiol. 59: 247259, 2016.

19. Knechtle, B., Rosemann, T., Lepers, R. and Rüst, C.A. Women outperform men in ultradistance swimming: the Manhattan Island Marathon Swim from 1983 to 2013. Int. J. Sports Physiol. Perform. 9: 913-924, 2014.

20. Knechtle, B., Rosemann, T. and Rüst, C.A. Women cross the 'Catalina Channel' faster than men. Springerplus 4: 332, 2015.

21. Knechtle, B., Rosemann, T. and Rüst, C.A. Ice swimming and changes in body core temperature: a case study. Springerplus 4 : 394, 2015.

22. Mazarakis, A., Bardousis, K., Almpanis, G., Mazaraki, I., Markou, S. and Kounis, N.G. Kounis syndrome following cold urticaria: the swimmer's death. Int. J. Cardiol. 176: e52-e53, 2014.

23. McCullough, L. and Arora, S. Diagnosis and treatment of hypo- thermia. Am. Fam. Physician. 70: 2325-2332, 2004.

24. Molnar, G.W. Survival of hypothermia by men immersed in the ocean. J. Am. Med. Assoc. 131: 1046-1050, 1946.

25. Noakes, T.D., Dugasa, L.R., Tuckera, R., Oksab, J., Dunnc, J., van der Merwec, B.S., Dirkerc, J.A., Porvarid, K. and Smolandere, J. Body temperatures during three long-distance polar swims in water of $0-3^{\circ} \mathrm{C}$. J. Therm. Biol. 34: 23-31, 2009.

26. Nuckton, T.J., Claman, D.M., Goldreich, D., Wendt, F.C. and Nuckton, J.G. Hypothermia and afterdrop following open water swimming: the Alcatraz/San Francisco swim study. Am. J. Emerg. Med. 18: 703-707, 2000.

27. Polderman, K.H. Mechanisms of action, physiological effects, and complications of hypothermia. Crit. Care Med. 37: S186S202, 2009.

28. Rüst, C.A., Knechtle, B. and Rosemann, T. Changes in body core and body surface temperatures during prolonged swimming in water of $10^{\circ} \mathrm{C}$ - a case report. Extrem. Physiol. Med. 1: 8, 2012.

29. Sejersted, O.M. and Sjøgaard, G. Dynamics and consequences of potassium shifts in skeletal muscle and heart during exercise. Physiol. Rev. 80: 1411-1481, 2000.

30. Schaub, P., Knechtle, B., Rüst, C.A. and Rosemann, T. Differences in swimming speed between short and long course from $50 \mathrm{~m}$ to $1,500 \mathrm{~m}$ in elite female and male Swiss freestyle age group swimmers. Adapt. Med. 7: 186-195, 2015.

31. Wacharasint, P., Nakada, T.A., Boyd, J.H., Russell, J.A. and Walley, K.R. Normal-range blood lactate concentration in septic shock is prognostic and predictive. Shock 38: 4-10, 2012.

32. Wagner, S., Knechtle, B., Knechtle, P., Rüst, C.A. and Rosemann, T. Higher prevalence of exercise-associated hyponatremia in female than in male open-water ultra-endurance swimmers: the 'Marathon-Swim' in Lake Zurich. Eur. J. Appl. Physiol. 112: 1095-1106, 2012.

33. Zavorsky, G.S., Cao, J., Mayo, N.E., Gabbay, R. and Murias, J.M. Arterial versus capillary blood gases: a meta-analysis. Respir. Physiol. Neurobiol. 155: 268-279, 2007. 